\title{
PEMBUATAN SABUN CUCI PIRING CAIR UNTUK MENINGKATKAN PELUANG WIRAUSAHA IBU RUMAH TANGGA DI DESA MALAKA LOMBOK UTARA
}

\author{
Earlyna Sinthia Dewi ${ }^{1 *}$, Asmawati ${ }^{1}$, Syirril Ihromi, Nurhayati ${ }^{1}$ \\ Program Studi Teknologi Hasil Pertanian Universitas Muhammadiyah Mataram \\ Jalan KH. Ahmad Dahlan No. 1-2 Pagesangan Mataram \\ *Korespondensi: earlyna.rayes@gmail.com
}

Diterima 9 Oktober 2019 / Disetujui 17 Desember 2019

\begin{abstract}
ABSTRAK
Kurangnya pengetahuan masyarakat dalam proses pembuatan sabun cuci piring cair menyebabkan tertutupnya peluang bisnis di Desa Malaka, Kabupaten Lombok Utara. Tujuan kegiatan pengabdian kepada masyarakat ini yaitu sebagai upaya pemberdayaan ibu-ibu rumah tangga yang notabene sebagian besar bekerja sebagai buruh tani, dengan cara memberikan penyuluhan dan pelatihan secara langsung tentang proses pembuatan sabun cuci piring cair sehingga nantinya dapat membuka peluang wirausaha untuk meningkatkan pendapatan keluarga. Metode yang digunakan yaitu melalui ceramah, diskusi dan praktik atau demonstrasi. Hasil kegiatan menunjukkan bahwa masyarakat sudah mampu membuat sabun cuci piring cair sendiri atau secara mandiri sehingga peluang untuk membuka usaha semakin terbuka lebar.
\end{abstract}

Kata Kunci: pemberdayaan, pelatihan, sabun cuci piring, Desa Malaka

\section{PENDAHULUAN}

Desa Malaka merupakan salah satu dari empat desa yang ada di Kecamatan Pemenang, yang berjarak $\pm 10 \mathrm{~km}$ dari Pusat Kecamatan Pemenang dan $\pm 15 \mathrm{~km}$ dari Pusat Pemerintah Kabupaten Lombok Utara. Mata pencaharian utama penduduk Desa Malaka adalah nelayan dan buruh, baik sebagai buruh tani maupun buruh bangunan. Penghasilan yang minim dan kebutuhan hidup yang meningkat menyebabkan warga Desa Malaka memerlukan sumber penghasilan tambahan. Penghasilan tambahan ini dapat diupayakan oleh masyarakat dengan mendirikan industri rumahan seperti usaha pembuatan sabun cuci piring cair.
Penggunaan sabun cuci piring bisa dikatakan rutin digunakan sehari-hari karena berfungsi membersihkan kotoran atau lemak yang menempel pada piring, gelas, dan perabotan dapur lainnya. Umumnya, pengeluaran rutin oleh ibu rumah tangga setiap bulannya adalah membeli sabun cuci piring. Peningkatan penggunaan sabun cuci piring cair juga akibat dari adanya pergeseran kebiasaan. Ini terlihat dari konsumen yang sudah meninggalkan cara tradisional yaitu menggunakan sabun colek atau abu gosok.

Kehadiran sabun cuci piring cair ini memberikan nilai lebih dibandingkan sabun colek atau sabun krim lainnya, karena mudah larut dalam air, lembut di tangan, memberikan aroma segar dan 
ramah terhadap lingkungan. Keunggulan sabun cuci piring cair lainnya yakni lebih higenis karena biasanya disimpan dalam wadah yang tertutup rapat (Wijana dkk., 2009). Oleh karena itu, kebutuhan akan sabun cuci piring di masyarakat semakin meningkat. Masalah yang dihadapi oleh masyarakat desa yaitu minimnya pengetahuan masyarakat mengenai cara pembuatan produk sabun cuci piring cair sehingga menjadikan tertutupnya peluang bisnis di Desa Malaka.

Tujuan dari kegiatan pengabdian kepada masyarakat ini yaitu sebagai upaya pemberdayaan ibu-ibu rumah tangga yang yang notabene sebagian besar bekerja sebagai buruh tani dengan memberikan penyuluhan dan pelatihan secara langsung tentang proses pembuatan sabun cuci piring cair sehingga membuka peluang wirausaha untuk meningkatkan pendapatan keluarga.

\section{METODE KEGIATAN}

\section{Waktu dan Lokasi Kegiatan}

Program Pengabdian Kepada

Masyarakat ini telah dilaksanakan pada hari Kamis, 12 September 2019 bertempat di Halaman Masjid Dusun Teluk Kodek, Desa Malaka, Kabupaten Lombok Utara.

\section{Metode Pelaksanaan}

Metode yang digunakan dalam kegiatan ini yaitu melalui penyuluhan dan pelatihan secara langsung. Pelaksanaan dimulai dengan penyuluhan dalam bentuk ceramah dan diskusi langsung untuk mengetahui fungsi dari bahan-bahan yang digunakan dalam pembuatan sabun cuci piring cair dilengkapi formula dan diagram alir prosesnya. Tahapan selanjutnya adalah pelaksanaan pelatihan dan praktek pembuatan sabun cuci piring cair dengan melibatkan peserta secara langsung.

\section{Bahan dan Alat}

Bahan yang diperlukan dalam kegiatan ini antara lain: texapon, sodium sulfat, metain, glucotain, LABS, soda ash, pewangi, pewarna, dan air suling.

Peralatan yang digunakan antara lain baskom kecil, wadah plastik, pengaduk kayu, sendok, gelas ukur, kain lap, timbangan, dan botol plastik untuk kemasan.

Tabel 1. Komposisi pembuatan sabun cuci piring cair

\begin{tabular}{llrl}
\hline \multicolumn{1}{c}{ Bahan } & \multicolumn{1}{c}{ Fungsi } & Kuantitas & Satuan \\
\hline Texapon & Pengangkat kotoran dan penghasil busa & 100 & gram \\
Sodium sulfat & Pengental, pengangkat kotoran & 50 & $\mathrm{gram}$ \\
Metain & Memperbanyak busa & 10 & $\mathrm{ml}$ \\
Glucotain & Emulsifier & 5 & $\mathrm{ml}$ \\
LABS & Mengangkat lemak & 10 & $\mathrm{ml}$ \\
Soda ash & Meningkatkan daya bersih & 1 & $\mathrm{gram}$ \\
Pewangi & Memberikan aroma pada sabun & 5 & $\mathrm{ml}$ \\
Pewarna & Memberi warna pada sabun & 10 & $\mathrm{ml}$ \\
Air suling & Pelarut & 1 & liter \\
\hline
\end{tabular}

\section{HASIL DAN PEMBAHASAN}

\section{Evaluasi Kegiatan}

Kegiatan pengabdian ini diikuti oleh 42 peserta yang terdiri dari ibu-ibu rumah tangga dan wakil masyarakat, sedangkan tim pelaksana terdiri dari 4 orang. Evaluasi ini bertujuan untuk mengetahui tanggapan peserta terhadap kegiatan yang telah dilakukan. Tanggapan peserta mengenai kegiatan ini sangat positif, selain materinya 
mudah dipraktekkan, peserta juga mendapatkan motivasi untuk mengembangkan pembuatan sabun cuci piring ini sebagai wirausaha mandiri. Beberapa peserta masih belum memahami mengenai berapa jumlah takaran yang digunakan. Akan tetapi, kami tim pengabdian sudah membuat brosur yang berisi tentang formula dan tahapan pembuatan sabun cuci piring cair. Pembuatan sabun dengan tahapan dan takaran yang benar akan menghasilkan sabun cair yang berkualitas (Tanjung, 2017).

\section{Indikator Keberhasilan}

Kegiatan penyuluhan dan pelatihan pembuatan sabun cuci piring cair telah dilakukan dengan baik dan sesuai rencana. Peserta mengikuti kegiatan dengan antusias dan penuh semangat. Hasil kegiatan menunjukkan bahwa masyarakat sudah mampu membuat sabun cuci piring cair sendiri atau secara mandiri sehingga peluang untuk membuka usaha semakin terbuka lebar.

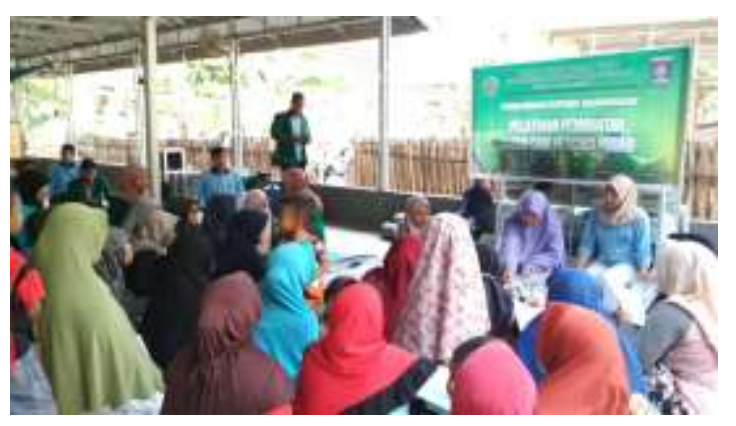

Gambar 2. Foto Kegiatan Penyuluhan

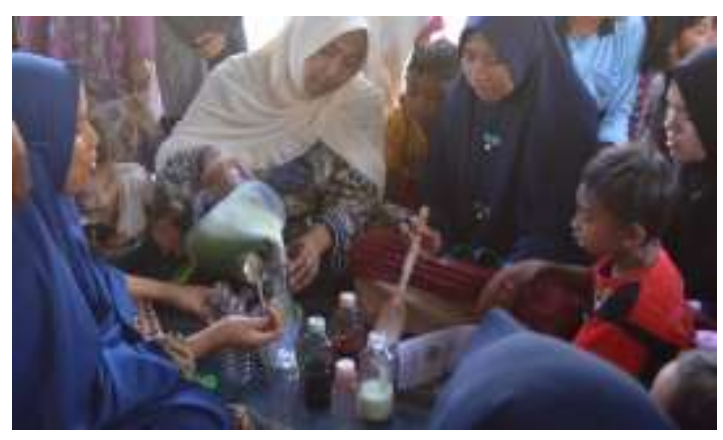

Gambar 3. Foto Kegiatan Pelatihan

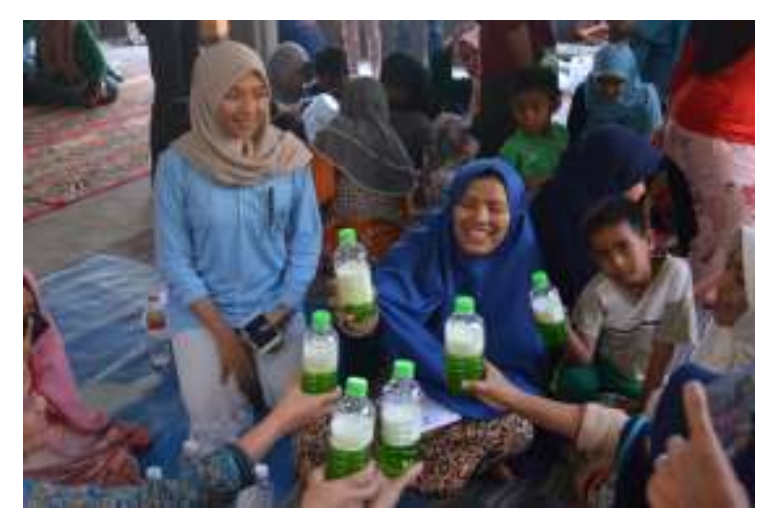

Gambar 4. Foto Produk Sabun Cuci Piring Cair

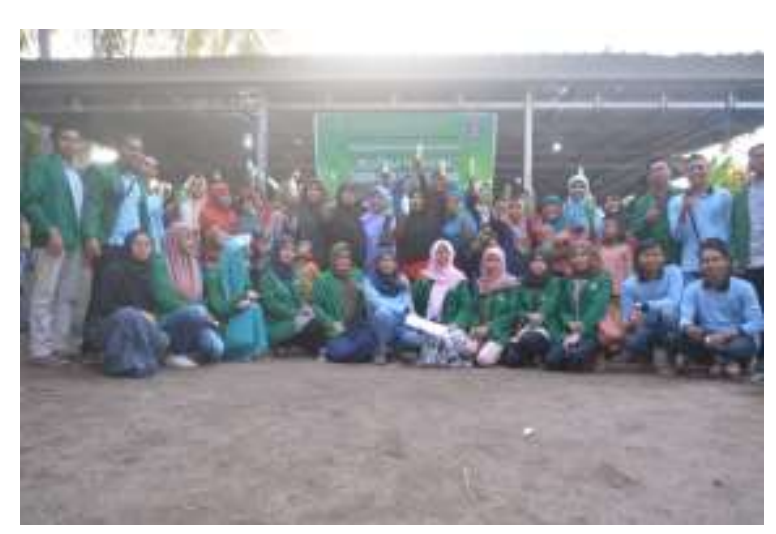

Gambar 5. Foto Bersama Peserta Pelatihan

\section{KESIMPULAN DAN SARAN}

\section{Kesimpulan}

Berdasarkan hasil pelaksanaan kegiatan pengabdian kepada masyarakat, dapat disimpulkan bahwa kegiatan penyuluhan dan pelatihan pembuatan sabun cuci piring cair berjalan dengan lancar sesuai rencana, kegiatan ini mampu meningkatkan keterampilan ibu-ibu rumah tangga di Desa Malaka dalam pembuatan sabun cuci piring cair yang dapat dijadikan sebagai peluang wirausaha.

\section{Saran}

Dalam pembuatan sabun cuci piring ini sebaiknya tahapan dalam memformulasikan bahan-bahannya harus sesuai dengan prosedur, karena apabila 
pembuatan sabun tidak dilakukan sesuai dengan prosedur, maka warna sabun yang dihasilkan akan terlihat keruh.

\section{UCAPAN TERIMA KASIH}

Terima kasih kami ucapkan kepada Lembaga Penelitian dan Pemberdayaan Masyarakat (LPPM) Universitas Muhammadiyah Mataram serta pihakpihak yang telah membantu terlaksananya kegiatan pengabdian ini sesuai dengan rencana dan target yang ditentukan.

\section{DAFTAR PUSTAKA}

Tanjung, D.A., 2017. Pelatihan Pembuatan Sabun Cair dan Shampoo Pencuci Mobil. Jurnal Prodikmas Hasil Pengabdian Masyarakat. 2(1): 41-45.

Wijana, S., Sumarjo, dan Harnawi, T., 2009. Studi pembuatan sabun mandi cair dari daur ulang minyak goreng bekas (Kajian pengaruh lama pengadukan dan rasio air: sabun terhadap kualitas). Jurnal Teknologi Pertanian, 10(1): 54-61. 